\title{
Experience of speech pathology and nutritional monitoring of oral feeding in older people from a community-based approach
}

\author{
Manuel Nibaldo del Campo Rivas ${ }^{1}$ \\ https://orcid.org/0000-0001-6076-2734 \\ Alejandra Patricia Ulloa Albornoz ${ }^{2}$ \\ https://orcid.org/0000-0002-4429-7374 \\ Pablo Andrés Haro Rivera ${ }^{2}$ \\ https://orcid.org/0000-0002-7436-0952 \\ Carolina Alejandra Orellana Venegas ${ }^{3}$ \\ https://orcid.org/0000-0003-4297-1254
}

Universidad Santo Tomás, Facultad de Salud, Escuela de Fonoaudiología, Viña del Mar, Valparaíso, Chile.

Universidad Santo Tomás, Facultad de Salud, Escuela de Nutrición y Dietética, Viña del Mar, Valparaíso, Chile.

Universidad del Desarrollo, Facultad de Medicina-Clínica Alemana, Carrera de Fonoaudiología, Santiago de Chile.

Research support source: Initiation Project-2018. Universidad Santo Tomás, Chile. TAS: 0000034142.

Conflict of interests: Nonexistent

\section{(c) (i)}

Received on: December 15, 2020 Accepted on: August 30, 2021

Corresponding address:

Manuel del Campo Rivas

Escuela de Fonoaudiología

Avenida Uno norte $3041,5^{\circ}$ piso

Código Postal: 2561694 - Viña del Mar,

Valparaíso, Chile

E-mail: mdelcampo2@santotomas.cl

\section{ABSTRACT}

Purpose: to describe the changes in the body composition and swallowing of an olderpeople group from a community-based speech therapy and nutrition program.

Methods: a pre-experimental study of a single group was carried out, with prospective timing and pre-post evaluation for three months. The Body Mass Index (BMI), percentage of body fat (\%BF), percentage of muscle mass (\%MM), percentage of visceral fat (\%VF), swallowing performance, and Swallowing Quality of Life (Swall-QoL) were evaluated. The Spearman correlation coefficient and the Mann-Whitney $U$ test were used, significance level $p<0.05$.

Results: 13 older people participated in the study. The average age of the group was 73.8 years $(S D=4.6)$. The $B M I$ ( $p r e=28.17$; post $=28.38), \% B F \quad(p r e=38.5$; post $=38.7)$, \%MM (pre=24.8; post $=24.9$ ) and $\% \mathrm{VF}($ pre $=14.3$; post $=14.8)$ did not present significant differences $(p>0.05)$. The scores obtained in the deglutition test was pre $=19.15$ and post $=18.9$. An association between $B M I$ and $V F(R h o=0.74$; $\mathrm{p}=0.02$ ) was detected.

Conclusion: the program represented a community-based instance of health promotion focus on oral feeding of older people.

Keywords: Deglutition; Aging; Speech-Language Pathology; Eating; Nutritional Sciences 


\section{INTRODUCTION}

Aging represents a social phenomenon ${ }^{1}$ characterized by anatomical, physiological changes that increase the susceptibility of the elderly to risk factors that can affect their health ${ }^{2}$. As of 2013, there were $2,855,157$ people over 60 years old $^{3}$ in Chile, and this number seems to be increasing as a result of the growing life expectancy of this population ${ }^{4}$.

Studying the phenomena that affect this group's health and quality of life is a priority issue for all countries $^{5}$. Older people notice a generalized deterioration of systems that can affect functions such as food intake, an act that, if compromised, can be life-threatening ${ }^{6}$.

Swallowing is a complex process that involves voluntary and reflex behaviors, its purpose is to move food from the mouth to the stomach ${ }^{7}$, and it is a relevant activity for the maintenance of life ${ }^{8}$.

As age advances, physiological changes in the body composition happen, which can impair swallowing ${ }^{9}$, resulting in an increased risk for the development of swallowing disorders ${ }^{10}$.

The body composition changes during life, first increasing and then stabilization and/or decrease in senescence ${ }^{11}$. These changes are dynamic and can mimic some conditions that become pathological ${ }^{11}$, such as pre-sarcopenia and sarcopenia. Sarcopenia is defined as a decrease in skeletal muscle associated with age, contributing to the loss of independence in older people ${ }^{12}$. Sarcopenia can affect complex functions such as swallowing through a condition that has been defined as sarcopenic dysphagia. Sarcopenic dysphagia is a phenomenon observed in some people aged 60 years or older, and it is defined as a swallowing difficulty associated with the loss of mass, strength, and functionality of the general musculature and that associated with the act of swallowing, which can compromise the quality of life and the vital state of the subjects ${ }^{13}$.

The quality of life has different dimensions, associated with a satisfactory life situation and the subjective perception of well-being, positive selfassessment, and belonging to a group or community ${ }^{14}$. The literature indicates that there is a link between body composition and dysphagia in older people ${ }^{15}$. Swallowing disorders can affect people's quality of life, noticing that the act of swallowing has a social dimension that finally occurs within a human group or community and that its condition can compromise those who suffer from some type of disorder ${ }^{16}$.
Additionally, it is interesting to consider the community-based rehabilitation approach as an ideal strategy to approach human groups in a collaborative social context ${ }^{17}$. This perspective offers a way of connecting with people, not from the hierarchical relationship of the biomedical model, but from an integrating position that recognizes the reality of the territory and its inhabitants, as a source from which a two-way relationship can be started ${ }^{18}$.

The objective of this research was to describe the changes generated in the body composition and swallowing of a group of older people from a community-based program of speech and nutritional support.

\section{METHODS}

This research was approved by the Scientific Ethics Committee (SEC) of Santo Tomás University, Chile, with code 18.18. Additionally, informed consent was available through which the participants authorized their free and voluntary participation in the study.

A single-group pre-experimental study was carried out, with prospective timing and pre-post evaluation ${ }^{19}$. The intervention activities included group instances of approach and speech therapy education, execution of workshops to prepare food minutes, and actions to stimulate the muscles related to swallowing according to a weekly topic (Appendix 1).

The universe consisted of 15 older people belonging to a Neighborhood Council of the Los Limonares community in Viña del Mar, Fifth Region of Valparaíso, Chile. The sample size calculation was performed with the $G$ * Power $3.1^{20}$ Software considering an effect size of 0.9 , error of 0.05 and power 0.95 , estimating a necessary sample of 15 subjects. The inclusion criteria were the absence of a moderate or severe swallowing disorder after triage assessment with the Gugging Swallowing Screen (GUSS) ${ }^{21}$, age equal to or greater than 60 years, and the signing of the informed consent. The exclusion criteria were reduced mobility, physiological instability due to uncontrolled pathologies, neuropsychological or mental disorder that disabled the person to follow instructions.

The variables of interest related to body composition were body mass index, percentage of visceral fat, percentage of body fat, percentage of muscle mass and grip strength. Concerning swallowing, the following were evaluated: phonoarticulatory organs, swallowing performance, and quality of life associated with swallowing. 
To collect the information, the Gugging Swallowing Screen (GUSS)21, Swallowing Quality of Life Questionnaire ${ }^{22}$, bioimpedance meter (Bodystat 500), DM001 digital dynamometer, and a self-created guideline for the evaluation of phonoarticulatory organs were used. The said guideline included the clinical assessment of speech-articulatory structures, symmetry, mimicry, and facial typology, and a tactile assessment of the facial muscles carried out from a qualitative assessment by a trained clinical speech therapist.

As a first step, community leaders were contacted to access older people in the territory respectfully. Once the links were generated, the project's scope was shared with the group, managing the informed consents communication, and offering reasonable times for their review, signature, and return.

The follow-up period considered an initial and a final assessment and ten weekly workshops, in sessions of approximately 60 minutes, for three months during 2018.

Descriptive and non-parametric inferential statistics were used, particularly Spearman's Rho and Mann Whitney's $U$, considering a significance level of $p$ $<0.05$. The data obtained were tabulated in Microsoft Excel 2010 and subsequently analyzed in Graph Pad Prism 5.0.

\section{RESULTS}

The group of older people was evaluated by professional speech therapists and nutritionists-dieticians, identifying a total of 13 subjects that made up the final sample. The description of the participants is detailed in Table 1, highlighting an average age of 73.8 years old $(S D=4.6) .67 \%$ of the participants corresponded to females, and $44 \%$ of the individuals were overweight. Most of the people (92.3\%) had a removable prosthetic implant.

Table 1. Characteristics of the Single Group

\begin{tabular}{|c|c|c|c|c|c|c|}
\hline Parameter & & & & & & \\
\hline Age & Average & 73 & Min & 64 & $\operatorname{Max}$ & 81 \\
\hline Gender & Female & $67 \%$ & Male & $33 \%$ & non determined & - \\
\hline Height & Average & $1.55 \mathrm{~m}$ & Min & $1.44 \mathrm{~m}$ & $\operatorname{Max}$ & $1.68 \mathrm{~m}$ \\
\hline Weight & Average & $69 \mathrm{~kg}$ & Min & $48.5 \mathrm{Kg}$ & Max & $95.3 \mathrm{Kg}$ \\
\hline $\mathrm{BMI}$ & LW $12 \%$ & NW 22\% & OW 44\% & OB 22\% & - & - \\
\hline Facial structure & Mesofacial & $84.6 \%$ & Dolichofacial & $7.7 \%$ & Brachyfacial & $7.7 \%$ \\
\hline Facial symmetry & Normal & $92.3 \%$ & Altered & $7.7 \%$ & & \\
\hline Upper dental arch & NP & $7.7 \%$ & WP & $92.3 \%$ & & \\
\hline Lower dental arch & NP & $7.7 \%$ & WP & $92.3 \%$ & & \\
\hline
\end{tabular}

Captions: Aver= average; $\operatorname{Min}=$ minimum; $M a x=$ Maximum; $B M I=$ Body Mass Index

$\mathrm{LW}=$ Low Weight; $\mathrm{NW}=$ Normal Weight; $\mathrm{OW}=$ Overweight; $\mathrm{OB}=$ Obesity; NP= No Prosthetics; $W P=$ With Prosthetics.

The body mass index (BMI), the percentage of body fat, the percentage of muscle mass, and the percentage of visceral fat did not register statistically significant differences between both evaluation times $(p>0.05)$ (Figure 1).
Regarding the swallowing act, a standard assessment was observed in the participants from the screening test (GUSS); therefore, no instrumental evaluation was required, noticing scores higher than 18 for both times. The quality of life associated with swallowing (Swal-Qol) showed a slight increase that was not significant (Table 2). 


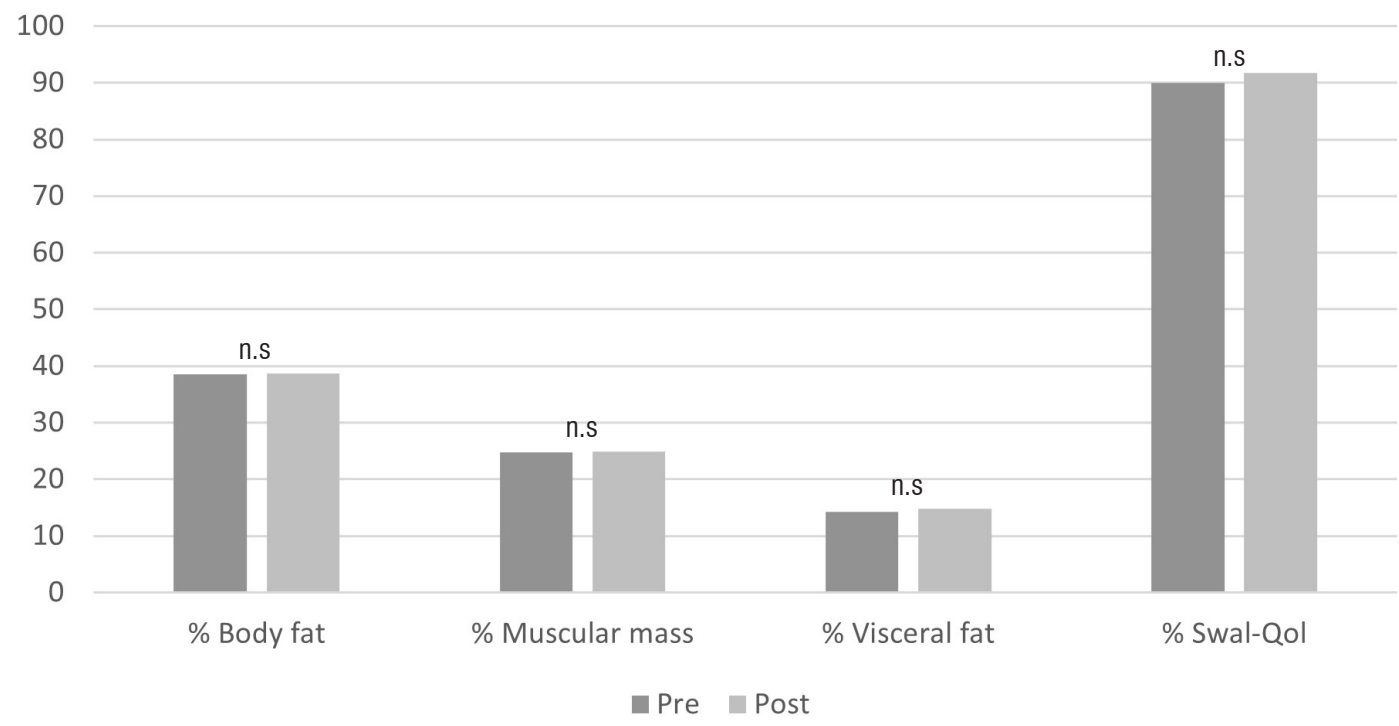

Captions: Swal-Qol= Swallowing Quality of Life Questionnaire. U de Mann- Whitney test. n.s. $=$ non significant $(p>0.05)$.

Figure 1. Body composition and quality of life associated with swallowing

Table 2. Comparison of nutritional parameters and swallowing screening

\begin{tabular}{cccc}
\hline Parameter & Pre & Post & p-value \\
\hline BMl & 28.17 & 23.38 & 0.92 \\
Grip Strength & 15.7 & 16.7 & 0.47 \\
GUSS & 19.15 & 18.9 & 0.3 \\
\hline
\end{tabular}

Captions: BMI = Body Mass Index; GUSS = Gugging Swallowing Screen. U de Mann- Whitney test. ${ }^{\star} p<0.05$.

$33 \%$ of the sample had a high percentage of body fat, and $67 \%$ were categorized as having very high body fat for their gender and age. The association analysis detected a direct and statistically significant relationship between $\mathrm{BMI}$ and visceral fat (Rho $=0.74 ; p=0.02)$. A slight change was observed regarding grip strength before and after the intervention; both measures were below the $25^{\text {th }}$ percentile for both hands, with an average score of 15.7 and 16.7, respectively (Table 2).

\section{DISCUSSION}

The body composition, nutritional status, and swallowing in older people are relevant health dimensions to address for the identification, screening, and prompt treatment of aging-related symptoms and the possible effects these may have on the well-being and quality of life of this population ${ }^{23}$. The nutritional profile observed in the elderly in the studied community agrees with the nutritional status due to excess reported in the National Health Survey in $2017^{24}$, with a prevalence of overweight greater than $60 \%$ at a national level.
This study showed that, despite an increase in body and visceral fat, with a decrease in lean mass, no related swallowing complaints were noticed in the evaluated users. Likewise, a slight decrease was noted in the GUSS screening test scores (Table 2). This may be due to excellent knowledge that people had regarding swallowing after monitoring. Likewise, it was observed that the experience, although it did not generate significant changes in the health fields evaluated, it did not deteriorate them.

Recent studies referring to the comprehensive approach to nutrition in older people have focused on evaluating the effectiveness of exercise-based interventions and a nutritional approach to prevent sarcopenia, demonstrating that these proposals have good acceptability in the population ${ }^{25}$. For example, a 6-month nutritional program aimed at the elderly can increase protein consumption by subjects living in adult communities ${ }^{26}$, and nutritional interventions in sarcopenia can prevent muscle loss in individuals undergoing intervention ${ }^{27}$. In line with the increase in the functionality of the elderly, a 
type III randomized controlled clinical trial reported that a program that included nutritional counseling, physical activity, dietary intervention, and the use of technologies was cost-effective versus an education program focused on promoting healthy lifestyles and aging ${ }^{28}$.

The specialized literature mentions that the comprehensive approach of swallowing in the elderly from the nutritional and speech therapy perspectives has made it possible to prevent, diagnose, treat, and rehabilitate the processes involved in oral feeding. These aspects turn out to be essential for the maintenance of life ${ }^{29}$.

Thus, the need to review the use and application of the concept of integrality is noted when it comes to approaching the elderly. It is necessary to incorporate different perspectives and areas of intervention that can impact the health status of the intervened subjects in the medium and long term.

It is necessary to design support programs where the times and areas of intervention, frequency, and monitoring of the population studied can be increase $d^{30,31}$ to show changes in the body composition and thus demonstrate the effectiveness of a comprehensive approach through studies that consider a more extensive population base and incorporate control groups.

On the other hand, it highlights the need to strengthen instances of health education in groups of older people who consider the reality of the territories. This aimed at empowering the subjects regarding the control of their own health.

The community and comprehensive approach towards older people has not been previously described at the local level, and seems to represent an instance for promoting health and preventing disorders in individuals who can be susceptible to risk.

The limitations observed in this study are the lack of an instrumental evaluation of swallowing that complements and objectifies the clinical assessment carried out, particularly regarding the state and functionality of the muscles involved in the process. Likewise, it is crucial to interpret the findings cautiously considering the methodology used, the final number of participating subjects (losses), and the follow-up time.

Given the epidemiological profile of the Chilean population $^{32}$, it is necessary to strengthen research in areas that contribute to maintaining the functionality and autonomy of the elderly, aligned with the country's health objectives ${ }^{33}$, to avoid the development of symptoms and / or disorders that may compromise the vital status and quality of life of the elderly. In this sense, the study of sarcopenia ${ }^{12}$ and its implications from nutrition and speech therapy ${ }^{34}$ will represent a promising research area for future projects.

\section{CONCLUSION}

The community-based speech therapy and nutritional monitoring described did not generate statistically significant changes in swallowing or nutritional aspects of the intervened group. The maintenance of the parameters studied in the elderly for the study's execution period was noticed. The comprehensive approach of oral feeding of older people without clinical symptoms represents an opportunity for health promotion and prevention of disorders associated with swallowing.

Likewise, it is an instance where it is possible to educate about the changes inherent to aging and identify signs that may require consulting a specialist or a health center. The community approach offers a scenario where accompaniment actions are designed to consider the needs of the population. The experience presented turned out to be a health-promoting instance within a community context, incorporating educational aspects and intervention at the individual and group level, helping to maintain functions that promote safe and effective oral feeding.

\section{ACKNOWLEDGEMENTS}

To Leonel Castillo Tapia, Nathaly Sepúlveda Sepúlveda, Sigrid Espinoza Muñoz, Pamela Estay Jorquera, Sebastián Vásquez Quijón, and Scarlet Contreras Madero for their valuable contribution.

\section{REFERENCES}

1. Alvarado A, Salazar M. Análisis del concepto de envejecimiento. Gerokomos [journal on the Internet]. 2014 [accessed on 2018 May 05]; 25(2):57-62. Available at: https://doi.org/10.4321/ S1134-928X2014000200002

2. Lehr U, Thomae H. Psicología de la senectud: proceso y aprendizaje del envejecimiento. 1st ed. Barcelona: Herder; 2003.

3. MDSF: Ministerio de Desarrollo Social y Familia de Chile. Encuesta de Caracterización Socioeconómica Nacional (CASEN). 2013 [accessed on 2018 Jun 05]. Available at: http:// observatorio.ministeriodesarrollosocial.gob.cl/ casen-multidimensional/casen/casen_2013.php 
4. Barahona-Urbina P. Factores determinantes de la esperanza de vida en Chile. An Fac Med [journal on the Internet]. 2011 [accessed on 2018 May 05]; 72(4):255-9. Available at: http://www.scielo. org.pe/scielo.php?script=sci_arttext\&pid =S1025$55832011000400006 \&$ lng =es.

5. OMS: Organización Mundial de la Salud. Envejecimiento y salud. 2018 [accessed on 2018 Jun 12]. Available at: http://www.who.int/ mediacentre/factsheets/fs404/es/

6. Cámpora $H$, Falduti A. Evaluación y tratamiento de las alteraciones de la deglución. Rev Am Med Resp. 2012;12(3):98-107.

7. Matsuo K, Palmer J. Anatomy and physiology of feeding and swallowing: normal and abnormal. Phys Med Rehabil Clin N Am [journal on the Internet]. 2008 [accessed on 2018 Jun 03]; 19(4):691-707. Available at: https://doi. org/10.1016/j.pmr.2008.06.001

8. Chee $\mathrm{C}$. The influence of chemical gustatory stimuli and oral anaesthesia on healthy human pharyngeal swallowing. Chem. Senses [journal on the Internet]. 2005 [accessed on 2018 Apr 21]; 30(5):393-400. Available at: https://doi.org/10.1093/chemse/bji034

9. Rosenberg I. Sarcopenia: origins and clinical relevance. J. Nutr. 1997;127(5 Suppl):990S-991S.

10. Yokoyama M, Mitomi N, Tetsuka K, Tayama N, Niimi S. Role of laryngeal movement and effect of aging on swallowing pressure in the pharynx and upper esophageal sphincter. Laryngoscope [journal on the Internet]. 2000 [accessed on 2018 Jun 12]; 110(3):434-9. Available at: https://doi. org/10.1097/00005537-200003000-00021

11. Gómez-Cabello A. Envejecimiento y composición corporal: la obesidad sarcopénica en España. Nutr Hosp [journal on the Internet]. 2012 [accessed on 2018 Jun 17]; 27(1):22-30. Available at: https://doi. org/10.3305/nh.2012.27.1.5502

12. Burgos R. Sarcopenia en ancianos. Endocrinol Nutr [journal on the Internet]. 2006 [accessed on 2018 May 21]; 53(5):335-44. Available at: https:// doi.org/10.1016/S1575-0922(06)71113-5

13. Patino-Hernandez D, Borda $M$, Venegas $L$, Chavarro-Carvajal D, Cano-Gutiérrez C. Disfagia sarcopénica. Rev Col Gastroenterol [journal on the Internet]. 2016 [accessed on 2018 Jun 22]; 31(4):418-23. Available at: http://www.scielo.org. co/scielo.php?script =sci_arttext\&pid = S0120 99572016000400012\&lng=en
14. Vera M. Significado de la calidad de vida del adulto mayor para sí mismo y para su familia. An Fac Med. 2007;68(3):284-90.

15. Solis G. Relación entre composición corporal y presbifagia en personas mayores adscritas a clubes de adultos mayores de la Comuna de Chillán Viejo. Presentado en XI Congreso SOCHINUT; 2015; Concepción, Chile.

16. Macias M, Quintero S, Camacho R, Sánchez S. La tridimensionalidad del concepto de nutrición: su relación con la educación para la salud. Rev Chil Nutr [journal on the Internet]. 2009 [accessed on 2018 Jul 12]; 36(4):1129-35. Available at: https:// doi.org/10.4067/S0717-75182009000400010

17. MSPS: Ministerio de Salud y Protección Social. Lineamientos Nacionales de Rehabilitación Basada en Comunidad para Colombia - Versión para Validación. [accessed on 2018 May 12]. Available at: https://www.minsalud.gov.co/sites/rid/ Lists/BibliotecaDigital/RIDE/DE/PS/lineamientosnacionales-rbc.pdf

18. Guajardo-Córdoba A, Recabarren-Hernández E, Asún-Salazar D, Zamora-Astudillo C, Cottet-Soto P. Evaluación de la estrategia de rehabilitación de base comunitaria $(\mathrm{RBC})$ desde la perspectiva de la comunidad y los equipos locales de rehabilitación. Rev Fac Med [journal on the Internet]. 2015 [accessed on 2018 Jul 22]; 63(Sup):41-50. Available at: https://doi.org/10.15446/revfacmed. v63n3sup. 49333

19. Hernández-Sampieri R, Fernández-Collado C, Baptista-Lucio P. Metodología de la investigación. 5th ed. México, DF: McGraw-Hill; 2010.

20. Faul F, Erdfelder E, Lang A, Buchner A. G*Power 3: a flexible statistical power analysis program for the social, behavioral, and biomedical sciences. Behav Res Methods. 2007;39(2):175-91.

21. John J, Berger L. Using the Gugging Swallowing Screen (GUSS) for dysphagia screening in acute stroke patients. J Contin Educ Nurs [journal on the Internet]. 2015 [accessed on 2018 Apr 10]; 46(3):103-4. Available at: https://doi. org/10.3928/00220124-20150220-12

22. McHorney CA, Robbins J, Lomax K, Rosenbek JC, Chignell K, Kramer AE et al. The SWAL-QOL and SWAL-CARE outcomes tool for oropharyngeal dysphagia in adults: III. Documentation of Reliability and Validity. Dysphagia [journal on the Internet]. 2002 [accessed on 2018 Jun 03]; 
17(2):97-114. Available at: https://doi.org/10.1007/ s00455-001-0109-1

23. Muñoz M, Ezpeleta E, Enríquez, Rey M, Quintela V, Román A. Estrategia para la prevención de eventos adversos en el anciano hospitalizado. Gerokomos. 2009;20(3):118-22.

24. MINSAL: Ministerio de Salud de Chile. Encuesta Nacional de Salud 2016-2017. [accessed on 2018 Jun 02]. Available at: https://www.minsal. cl/wp-content/uploads/2017/11/ENS-2016-17_ PRIMEROS-RESULTADOS.pdf

25. van Dongen EJI, Haveman-Nies A, Wezenbeek NLW, Dorhout BG, Doets EL, de Groot LCPGM. Effect, process, and economic evaluation of a combined resistance exercise and diet intervention (ProMuscle in Practice) for community-dwelling older adults: design and methods of a randomised controlled trial. BMC Public Health [journal on the Internet]. 2018 [accessed on 2020 Jun 03]; 18(1):877. Available at: https://pubmed.ncbi.nlm. nih.gov/30005654/

26. Reinders I, Wijnhoven HAH, Jyväkorpi SK, Suominen MH, Niskanen R, Bosmans JE et al. Effectiveness and cost-effectiveness of personalized dietary advice aiming at increasing protein intake on physical functioning in communitydwelling older adults with lower habitual protein intake: rationale and design of the PROMISS randomized controlled trial. BMJ Open [journal on the Internet]. 2020 [accessed on 2020 Dec 01]; 10(11):e040637. Available at: https://bmjopen.bmj. com/content/10/11/e040637

27. Landi F, Sieber C, Fielding RA, Rolland Y, Guralnik J. Nutritional intervention in sarcopenia: report from the International Conference on Frailty and Sarcopenia Research Task Force. J Frailty Aging. 2018;7(4):247-52.

28. Landi F, Cesari M, Calvani R, Cherubini A, Di Bari $M$, Bejuit $R$ et al. The "Sarcopenia and Physical fRailty IN older people: multi-componenT Treatment strategies" (SPRINTT) randomized controlled trial: design and methods. Aging Clin Exp Res [journal on the Internet]. 2017 [accessed on 2020 Dec 03]; 29(1):89-100. Available at: https://pubmed.ncbi. nlm.nih.gov/28144914/

29. Tamura F, Kikutani T, Tohara T, Yoshida M, Yaegaki $\mathrm{K}$. Tongue thickness relates to nutritional status in the elderly. dysphagia [journal on the Internet]. 2012 [accessed on 2018 Jun 22]; 27(4):556-61. Available at: https://doi.org/10.1007/s00455-012-9407-z
30. Maeda K, Akagi J. Treatment of sarcopenic dysphagia with rehabilitation and nutritional support: a comprehensive approach. J Acad Nutr Diet [journal on the Internet]. 2016 [accessed on 2018 Mar 03]; 116(4):573-7. Available at: https:// doi.org/10.1016/j.jand.2015.09.019

31. Wakabayashi H, Sakuma K. Rehabilitation nutrition for sarcopenia with disability: a combination of both rehabilitation and nutrition care management. J Cachexia Sarcopenia Muscle [journal on the Internet]. 2014 [accessed on 2018 May 17]; 5(4):269-77. Available at: https://doi.org/10.1007/ s13539-014-0162-x

32. Ganga F, Santana M, González D, Rebagliati F. Rol del Estado frente al envejecimiento de la población: el caso de Chile. Convergencia. 2016;23(71):175-200.

33. MINSAL: Ministerio de Salud de Chile. Estrategia nacional de salud para el cumplimiento de los objetivos sanitarios de la década 2011-2020. [accessed on 2018 Jun 02]. Available at: http://www.bibliotecaminsal.cl/ estrategia-nacional-de-salud-metas-2011-2020/

34. Hashida N, Shamoto H, Maeda K, Wakabayashi $\mathrm{H}$, Suzuki M, Fujii T. Rehabilitation and nutritional support for sarcopenic dysphagia and tongue atrophy after glossectomy: a case report. Nutrition [journal on the Internet]. 2017 [accessed on 2018 Apr 07]; 35(1):128-31. Available at: https://doi. org/10.1016/j.nut.2016.11.003 


\section{APPENDIX 1. ACCOMPANIMENT PROGRAM}

\begin{tabular}{|c|c|c|c|}
\hline Week & Activity & Detail & Responsible professional \\
\hline 1 & Initial assessment & $\begin{array}{ll}\text { - } & \text { PAOs Evaluation } \\
\text { - } & \text { Swallowing screening (GUSS) } \\
\text { - } & \text { Evaluation of Swallowing Quality of Life (Swal-Qol) } \\
\text { - } & \text { Evaluation of the body composition: Height, Weight, } \\
& \text { Bioimpedanciometry }\end{array}$ & Speech Therapy and Nutrition \\
\hline 2 & Approach & - $\quad$ Oral health and hygiene workshop & Speech Therapy \\
\hline 3 & Approach & $\begin{array}{l}\text { - Educational workshop on chronic non- transmissible } \\
\text { diseases }\end{array}$ & Nutrition \\
\hline 4 & Approach & $\begin{array}{l}\text { - Swallowing physiology and muscle exercises workshop } \\
\text { (isotonic and isometric) }\end{array}$ & Speech Therapy \\
\hline 5 & Approach & - Healthy minute preparation workshop & Nutrition \\
\hline 6 & Approach & - $\quad$ Postural techniques workshop & Speech Therapy \\
\hline 7 & Approach & $\begin{array}{l}\text { - } \\
\text { Preparation workshop with products from the } \\
\text { complementary feeding program for the elderly (CFPE) }\end{array}$ & Nutrition \\
\hline 8 & Approach & - Workshop on the adaptation of utensils for food & Speech Therapy \\
\hline 9 & Approach & $\begin{array}{l}\text { - Workshop on food portions in homemade measures and } \\
\text { nutritional labeling }\end{array}$ & Nutrition \\
\hline 10 & Approach & $\begin{array}{ll}\text { - Educational workshop on essential nutrients, water, and } \\
\text { hydration }\end{array}$ & Speech Therapy \\
\hline 11 & Approach & - Workshop on consistency adaptation and food handling & Nutrition \\
\hline 12 & Final Assessment & $\begin{array}{ll}\text { - } & \text { PAOs Evaluation } \\
\text { - } & \text { Swallowing screening (GUSS) } \\
\text { - } & \text { Evaluation of Swallowing Quality of Life (Swal-Qol) } \\
\text { - } & \text { Evaluation of the body composition: Height, Weight, } \\
& \text { Bioimpedanciometry }\end{array}$ & Speech Therapy and Nutrition \\
\hline
\end{tabular}

Captions: PAOs = Phonoarticulatory Organs; GUSS= Gugging Swallowing Screen; Swal-Qol= Swallowing Quality of Life Questionnaire. 